\title{
ANALYSIS OF SOYBEAN TRADE STRATEGIES WITH FORWARD CONTRACTS ON THE CHICAGO STOCK EXCHANGE AND ON THE SPOT MARKET IN CASCAVEL, BRAZIL
}

Odilon Felipe Tavares Aguiar* Jonathan Dias Ferreira**

ABSTRACT: In the wake of frequent variables that interfere with the agricultural market, rural agents (producers) suffer liabilities due to their decisions, especially at the moment of commercialization. The forward market is precisely a strategy that may reduce the risks in oscillating prices of commodities and makes way towards the future formation of prices. Current paper compares the commercialization of soybeans in the forward and spot markets in terms of prices practiced between the harvest years 2011/2012 and 2016/2017. Data provided by the Chicago Board of Trade (CBOT) were used as reference for forward contracts traded in September with maturation in January and spot prices practiced in January retrieved from data from Coopavel in Cascavel PR Brazil. Forward contracts traded in September with maturity in January had a better performance when compared to January spot prices for harvests 2011/2012, 2012/2013, 2013/2014. Due to fluctuations in weather and market trends, they were the factors that weighed most on harvests 2014/2015, 2015/2016 and 2016/2017 for better prices on most of the maturities for January on the spot market. Results show that, although spot price was better in certain periods, the marketing strategy on forward markets is highly interesting since the producer can employ profits and have guarantees against market risks.

KEY WORDS: Soybean. Forward Market. Spot Market. Agribusiness.

\section{ANÁLISE DAS ESTRATÉGIAS DE COMERCIALIZAÇÃO DA SOJA COM CONTRATOS FUTUROS DA BOLSA DE ÇHICAGO E SPOT EM CASCAVEL PARANÁ BRASIL}

RESUMO: Diante das frequentes variáveis que interferem no mercado agrícola, os agentes (produtores rurais) acabam sendo prejudicados em suas tomadas de decisão, sobretudo no momento de comercialização. E o mercado futuro surge como estratégia que pode reduzir os ricos em oscilação de preços das commodities e abre

\footnotetext{
"Discente do MBA em Gestão do Agronegócio da Fundação Assis Gurgacz - FAG, Cascavel, Paraná, Brasil.

** Mestre em Desenvolvimento Regional e Agronegócio pela Universidade Estadual do Oeste do Paraná. Docente convidado do Departamento de Pós-graduação da Fundação Assis Gurgacz - FAG, Cascavel, Paraná, Brasil. E-mail: jonathanferreiraa@hotmail.com.
} 
possibilidade para uma formação futura de preço. Dessa forma, este artigo objetivou apresentar uma comparação entre comercialização de soja realizada no mercado futuro e no spot em termos de preços praticados no período que compreendeu os anos safras 2011/2012 aos anos safras 2016/2017. Para isso utilizou-se como dados as cotações fornecidas na Chicago Board of Trade - CBOT, como referência aos contratos futuros negociados em setembro com vencimento em janeiro e os preços via spot praticados em janeiro conforme dados coletados junto à Coopavel em Cascavel (PR). Como análise, os contratos futuros negociados em setembro, com vencimento em janeiro, obtiveram melhor desempenho em comparação aos preços de janeiro spot nas safras: 2011/2012, 2012/2013, 2013/2014. No entanto, com as oscilações de clima e tendências de mercado, foram os fatores que mais pesaram para que as safras de 2014/2015, 2015/2016 e 2016/2017 apresentaram melhores preços na maioria dos vencimentos para janeiro no spot. Pode-se concluir, mesmo que o preço spot tenha sido melhor em dados períodos, a estratégia de comercialização no mercado futuro mostrou-se interessante, pois o produtor pode valer-se dos ganhos e ainda garantir-se dos riscos de mercado.

PALAVRAS-CHAVE: Agronegócio; Mercado futuro; Mercado spot; Soja.

\section{INTRODUCTION}

Soybean production in Brazil has earned a significantly relevant rank as an agricultural commodity. Data on the 2017/2018 soybean harvest, retrieved from the Brazilian Supply Company (CONAB) (2018), revealed an increase in crop cultivation area, volume and productivity. In fact, cultivated area increased by 3.7\% (35.1 million hectares); productivity increased by $0.9 \%$ (3,394 $\mathrm{kg}$ per hectare) and production had a $4.6 \%$ increase, with a record of 119 million tons.

Soybean has a unique $53.8 \%$ of a total of 221 million tons of grains produced in Brazil in the 2017/2018 harvest. In fact, it is the principal agricultural commodity, followed by corn, with $36.2 \%$. In other words, the two commodities reached $90 \%$ of total grain volume produced in Brazil (CONAB, 2018).

One should underscore than Brazil ranks second in world soybean production. According to supply and demand estimates for the 2018/2019 harvest, the US Department of Agriculture (2018) estimates that US production will reach a 
record of 125 million tons, closely followed by the Brazilian estimate at 120.5 million tons and by the Argentina estimate at $\mathbf{5 5 . 5}$ million tons. The three countries may represent $82 \%$ of world production for the $2018 / 2019$ harvest, estimated at 367.5 million tons.

Data from the 2017-2018 harvest revealed that Brazil is the greatest exporter of soybean grains, with 76 million tons, in front of the US with 57.9 million (MAPA, 2018). On the other hand, crop producers are always liable to risk conditions as to amount, time and mode of producing and marketing.

Uncertainties on soybean production are subjected to risk factors between production and commercialization. The primary risk consists of losses caused by pests and climate factors, followed by risks caused by price fluctuations, difference between supply and demand, and by increasing competition within the agricultural commodity market. In the wake of such uncertainties, the comprehension of the necessary basic procedures is required so that producers understand and participate in the novel commercialization media. Market strategies of price risks are required so that agribusiness managers become experts in the commercialization process of agricultural products, with profits.

The price received by producers in the trading of soybeans is determined by supply and demand in Brazil and worldwide. Great variability is extant and no individual producer may modify it. In other words, producers are mere price takers of the market. Consequently, data on the soybean market system may decrease uncertainties among producers. Uncertainties are characterized by the physical market, on the spot and in the forward markets, through hedge operation on the stock exchange, such as the B3 in São Paulo, Brazil, and the Chicago Board of Trade (CBOT) in the US.

Motter (2001), Marques \& Aguiar (2004), Mendes (2007), Mendes \& Batista (2008), Maia \& Aguiar (2010), Zavaglia, Mastella \& Kloeckner (2011), Lorenzetti \& Leismann (2018), Oliveira Junior et al. (2018) underscore forward contracts as agricultural commercialization strategies to reduce risks inherent to business. According to these authors, although most Brazilian producers have greatly difficult in the above factors, it is an available option as an operation by which the producer reduces market risks. 
Motter (2001) argues that soybean producers should analyze a great number of data so that they could put them into practice, such as tools and decisiontaking service. Actually, profits in agribusiness have been a challenge in the wake of the powerful segments that make up the system and trigger a warning sign for the producer on the profitability of the business.

Marques \& Aguiar (2004) investigated the determining factors in the use of forward markets by soybean producers in the municipality of Cascavel, Brazil, and revealed that most producers failed to employ forward markets and did not have a commercialization plan for agricultural production. Such behavior denotes gaps in commercialization management, perhaps due to their low schooling level.

Maia \& Aguiar (2010) analyzed profits and hedge strategy risks with soybean forward contracts by CBOT for the Cascavel region and concluded that, in the case of buying hedge, July is the best month for contract. If employed between November and May, gross profit would be US\$2.24/sack, associated with a 0.82 risk. Purchase hedgers, on the other hand, insist that contracts in January are the best alternative. August-December contracts have a profit of US\$ $0.80 /$ sack, with a 0.78 risk.

Junior et al (2018) analyzed soybean exports from the state of Mato Grosso do Sul, Brazil, and argued that lack of a storage structure and deficient knowledge on forward markets by producers are the main motives for low participation in the commercialization model. They are mainly supplied by big agroindustries that sell or exchange fertilizers and pesticides in exchange for grain so that they may allure and maintain producers.

Current paper uses soybean commercialization strategy, in terms of prices, to compare forward contracts by CBOT and those practiced on the spot market in Cascavel PR Brazil. Data have been retrieved from the Chicago Board of Trade (CBOT) in the US since it is the main stock exchange worldwide in trade volume. One should underscore that commercialization is as important as increase in productivity. Knowledge on commercialization, analyses of strategies in agricultural commercialization and reducing business risks are survival factors in agriculture. The producer will have better results in profits at calculated risks. 


\section{THEORY}

\subsection{FORWARD MARKET EXCHANGE: CHICAGO BOARD OF TRADE (CBOT)}

Stock exchange is a trade liquidity center, a center for the formation of transparent and just prices, a center of market development, market regulating, regulation and monitoring of operations, disclosure of prices and education (JESUSLOPES, 2007). The Chicago Board of Trade (CBOT) is considered the greatest stock exchange of futures exchanges worldwide and of trade contracts with soybean grains, bran and crude oil. High liquidity in CBOT contracts is perhaps the main factor that triggers big market agents to operate in the exchange. In fact, current paper has retrieved CBOT data as reference for commercialization strategies in the Chicago exchange between 2011 and 2017.

According to Working (1953), hedgers prefer the imperfect hedge tool with low costs to an efficient hedge at higher costs. It is evident that liquidity is required so that forward contracts have lower costs. According to data retrieved from the financial broker CME Group (2016), participants of forward market may be divided into two main categories: hedgers and speculators. Forward markets exist for the protection or hedge defined as a risk management against price fluctuations in the purchasing and selling of commodities.

Within the context of futures operations, hedge may be defined as a counterweight transaction that involves a position in forward market opposed to the real position on the physical market. Since prices on the physical and forward markets of a commodity go together, every loss of profit on the physical market (cash) will be approximately compensated or will be counterbalanced in the forward market (CME GROUP, 2016).

Telser \& Higinbotham (1997) insist that benefits in organized markets are an increasing function in the number of potential participants who simultaneously reduce marginal costs. There is concrete evidence that traders or financial agents negotiate soybean on the CBOT since it offers greater liquidity and lower costs, such as commissions, rates and guaranteed margins (LAZZARINI, 1997).

In fact, the Chicago Board of Trade (CBOT) centralizes the world's biggest 
dealers who control price trends of soybean and its derivates, essentially export products. During the US harvest, Brazilian export level rates fall significantly and price formation consists of prices from byproducts bran and soybean oil. In the two cases, the price at producers' level depends on local competition with other purchasers, on the urgency of the firm to guarantee stocks for milling operations, transport costs and others.

Negotiated forward contracts on the exchange market are standardized. They are characterized by asset quality standards, quantity, delivery dates and liquidation procedures. Consequently, they comply with particulars of soybean chain contracts in CBOT, such that the negotiation object comprises yellow soybean $\mathrm{N} 2$ and swapped varieties established by the exchange market. The unit negotiated is 5,000 bushels (136.07145 ton). Soybean is rated in cents and quarters of cents per bushel $(27.21429 \mathrm{~kg})$. Maturity months are September, November, January, March, May, July and August. Last negotiation day is the day prior to the $15^{\text {th }}$ day of the month in which maturity occurs (CBOT, 1999).

\subsection{FORWARD MARKETS VERSUS PRODUCTION COSTS}

Since price formation in forward markets of agricultural commodities depends on the ever-changing environment, cost production data is paramount and an important tool in decision taking during commercialization.

Costs reflect attitudes, behavior and operation modes. Availability and quality of information make results efficient (MEGLIORINI, 2002). Consequently, measuring production costs is one of the determining factors for operation control, determination of profits and decision taking. Identifying production costs is highly relevant when hedge is undertaken since costs and margin expected to ensure price on the forward market are taken into consideration.

Commodities market and their negotiation and price volatility are determined by the harvest's virtual data, climate and agricultural market data. Through CBOT, traders become more flexible in the purchase of forward markets, buying and selling with caution, following a stream of favorable data, or not following the price of the product. One may state that the market moves up and down according to 
information, reflecting its values on the stock exchange.

The commercialization of agricultural and livestock commodities in forward markets is related to the use of derivatives. The latter are contracts that depend on the performance of other assets so that their value could be demonstrated or appreciated. Agricultural commodities are the assets of agricultural and livestock derivatives. According to Hull (1998), a soybean forward contract is an example of agricultural and livestock derivatives due to its derivation from soybean price.

Soybean commercialization strategies may occur at four types of market, namely, the physical market, also known as the spot market (cash); term market; forward market; option market. Each has a significant share in the commercialization of commodities worldwide. They are also employed within the internal market. They will be explained in the sections below.

\subsubsection{Spot Market}

Spot market denotes a type of market in which the producer sells soybeans and receives a certain amount of money in cash or at a given date. The spot market is characterized by great uncertainties with regard to the behavior of prices. In other words, the spot market is the price practiced on the day of purchase (AZEVEDO, 2001).

\subsubsection{Term Market}

Agreements between purchasing and selling parties of commodities are undertaken for liquidation at a pre-established date and for a determined price. In term contracts, when producers want to be protected, they quit market speculation and possible profit potential to shun liabilities. According to Marques \& Mello (1999), "the commercialization of green soybeans emerged as an alternative to obtain agricultural credit in the wake of its limited supply. Term refers to anticipated purchase of soybean by the industries and/or tradings through contracts" (REZENDE; ZYLBERSZTAJN, 2011, p. 156). 


\subsubsection{Forward Market}

Commodities in forward market are commercialized at a certain price, at a future date. Price risks are negotiated. It is a sort of protection against price uncertainties that involve purchase and selling operations, undertaken in electronic bidding sessions, involving contracts authorized by the stock exchange of futures for liquidation at a future date. Forward exchange markets establish conditions so that the formation of future prices may be a competitive process (MONTEZANO, 1987).

Table 1 shows the main differences in term and forward operations.

Table 1. Main differences in Term and Forward Markets

\begin{tabular}{|l|l|}
\hline \multicolumn{1}{|c|}{ TERM MARKET } & \multicolumn{1}{c|}{ FUTURE MARKET } \\
\hline Counter negotiation or on the stock exchange & Negotiation on the stock exchange only \\
\hline Physical delivery predominates & Financial liquidation predominates \\
\hline Customized assets & Standardized assets \\
\hline $\begin{array}{l}\text { Impossibility of finishing prior to the contract's s } \\
\text { liquidation date }\end{array}$ & Interchangeability of positions \\
\hline Lack of daily adjustments & Daily adjustments \\
\hline Risks are the total responsibility of the parties. & $\begin{array}{l}\text { Operations guaranteed by stock exchange } \\
\text { (Clearing Guarantee System) }\end{array}$ \\
\hline
\end{tabular}

Source: the authors, from data in Série Introdutória - Mercados Derivativos - BM\&FBOVESPA (2012).

\subsubsection{Option Market}

Option markets are another method to reduce price risks. Investor administers and controls price risks through certain options. There are two types of negotiated options: call option (purchase), with the right of purchasing a specific product for a determined price, during a determined period. On the other hand, put option (selling), with the right of selling at a certain date, at a determined price.

When the soybean producer buys a put option, he has the right to sell the commodity for a certain amount up to a future data; if the market shows a fall in price, he has the right to sell the product at the put price. If the market shows better prices, the producer sells the commodity on the spot market (SILVA NETO, 2002). 3 METHODOLOGY 
Current paper analyzes the commercialization performance of the commodity soybean in the forward market from CBOT-retrieved data and from spot market practiced according to data derived from counter prices referenced by the Cooperativa Agroindustrial de Cascavel (Coopavel), in Cascavel, western region of the state of Paraná, Brazil, between 2011 and 2017.

According to Gil (2002), methodology is basic for data collection and analysis spread throughout the investigation environment. Definitions show clearly where and how investigation starts and how data may be analyzed.

Current research, characterized by quantification in data and collection of information, is a comparative study on the performance of soybean commercialization operations in forward and spot markets. The descriptive method based on bibliographic research was employed. Behavioral data of forward and spot prices were obtained from Chicago Board of Trade for comparative parameters. Further, the performance of spot prices on the day of delivery of the physical product was also taken into account. It occurred on the first 15 days of January with spot prices practiced at Coopavel and in forward contracts negotiated in September, maturing in January of the following year, with sales up to the $15^{\text {th }}$ day of maturity of the contract negotiated during the month. Negotiation parameters were between September 2011 and 2016.

Prices were provided by CBOT in US dollars, with contracts negotiated in September, with maturity in January of the following year, from September 2011 to September 2016. Spot prices were those practiced on the counter from January 2012 to January 2017.

Data were grouped in Excel sheets, with negotiation and maturity dates, in ascending order, for the sake of comparison. Spot prices were similarly ordered, with contract maturing up to the $15^{\text {th }}$ day of the forward contract. Cash price of the commodity soybean was compared with the future price of each maturation day. When all simulations of trading undertaken in September and maturing in January, between 2011 and 2017, and spot trading in January, between 2012 and 2017, were done, one could compare and investigate results that demonstrated the behavior of the variables under analysis. 


\section{RESULTS AND DISCUSSION}

So that the agency of forward market operators may be determined, technicians widely employ price variation graphs plus other indexes that demonstrate market changes (BM\&F, 1998). In such conditions, competition through prices may deepen and cost administration will be the basic factor for the survival of producers and industries. Further, producers' profitability should be guaranteed. Otherwise, the expansion process would be reversed. Consequently, forward markets are an option to guarantee profitability.

Figure 1 shows the performance of forward contracts. One may perceive that forward contracts negotiated in September 2011, with maturity in January 2012, had the best commercialization prices when compared with spot sales in January 2012. The producer who had a forward contract during this period would have had a guaranteed price and would have obtained positive results when compared to spot prices.

\section{CONTRACTS 2011/2012 HARVEST}

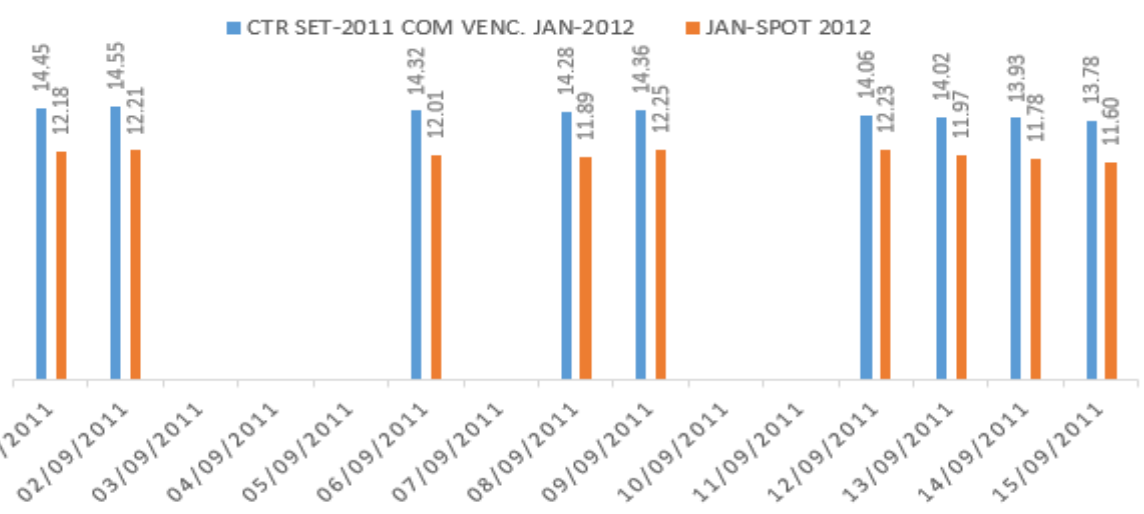

SEPT-2011, MATURING JAN-2012

Figure 1. Contracts negotiated in September 2011, with maturity in January 2012 and spot prices in January 2012

Source: The authors 
Figure 2 demonstrates that, in the case of contracts celebrated in September 2012, with maturity in January 2013, forwards contracts had better negotiable prices and were more profitable for the producer when compared to spot prices in January 2013.

\section{CONTRACTS 2012/2013 HARVEST}

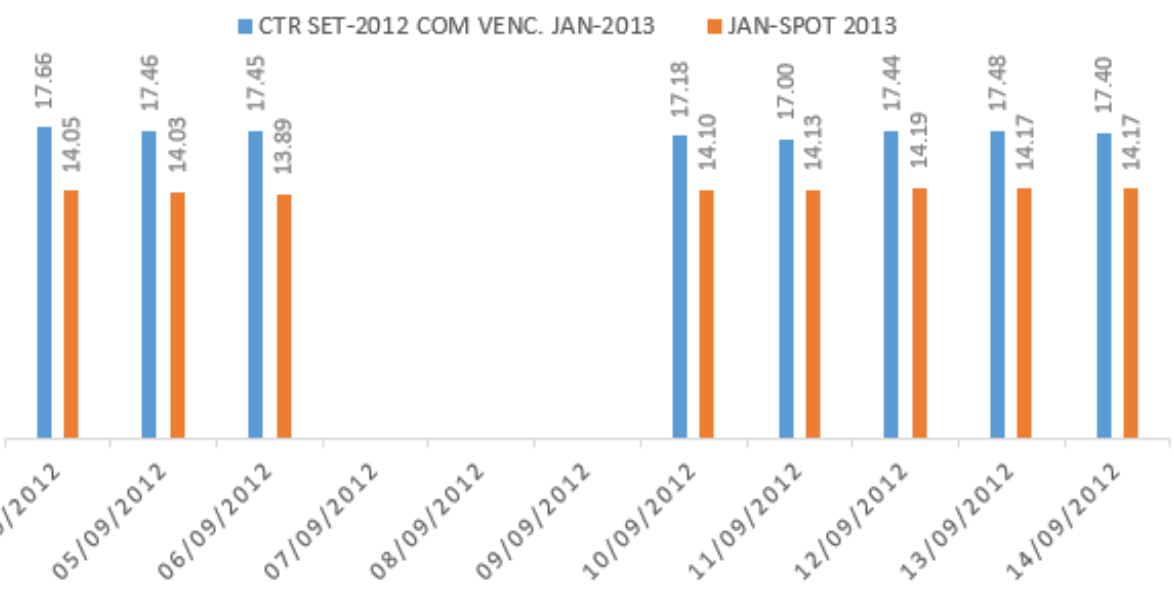

SEPT-2012, MATURING JAN-2013

Figure 2. Contracts negotiated in September 2012, with maturity in January 2013 and spot prices in January 2013.

Source: the authors

Figure 3 repeats the pattern perceived during the last years of analysis. Prices negotiated in forward contracts in September 2013, with maturity in January 2014, were satisfactory when compared to spot prices. 


\section{CONTRACTS 2013/2014 HARVEST}

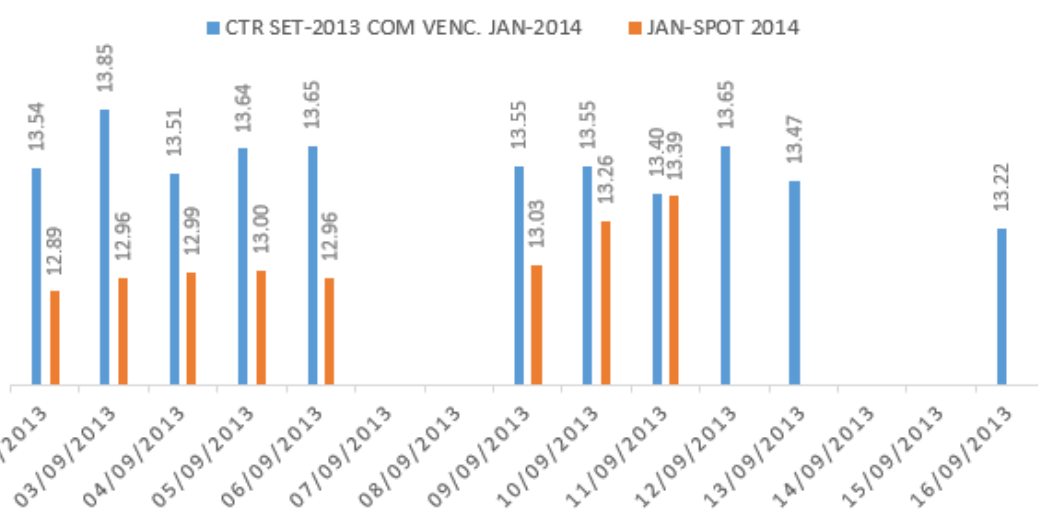

SEPT-2013, MATURING JAN-2014

Figure 3. Contracts negotiated in September 2013, with maturity in January 2014, and spot prices in January 2014. Source: the authors.

Figure 4 shows that forward contracts celebrated in September 2014, with maturity in January 2015, had lower prices when compared to spot prices in January 2015. Consequently, there was a price inversion when compared to results from 2011/2012, 2012/2013 and 2013/2014 harvests, where best prices in forward market were predominant.

\section{CONTRACTS 2014/2015 HARVEST}

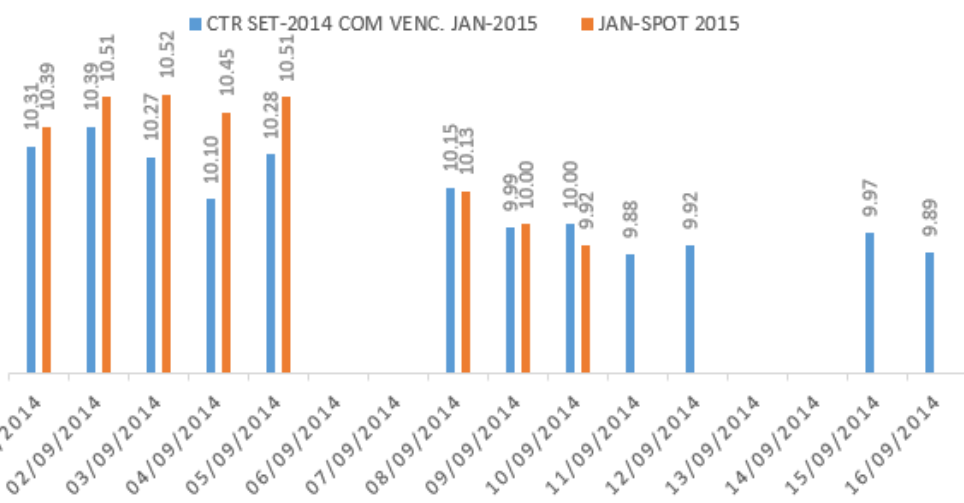

SEPT-2014, MATURING JAN-2015

Figure 4. Contracts negotiated in September 2014, with maturity in January 2015, and spot prices in January 2015. Source: the authors 
It should be underscored that, even if spot prices are better on the average, forward contracts are still highly interesting since they are a type of price guarantee. Producers would not have necessarily any liabilities, but would have had greater profits on the spot market.

Figure 5 shows that forward contracts negotiated in September 2015, with maturity in January 2016, had higher rates on specific maturity dates. However, the spot market in January 2016 proved to be better when compared to forward contract negotiated in September 2015.

\section{CONTRACTS 2015/2016 HARVEST}

\# CTR SET-2015 COM VENC. JAN-2016 \# JAN-SPOT 2016

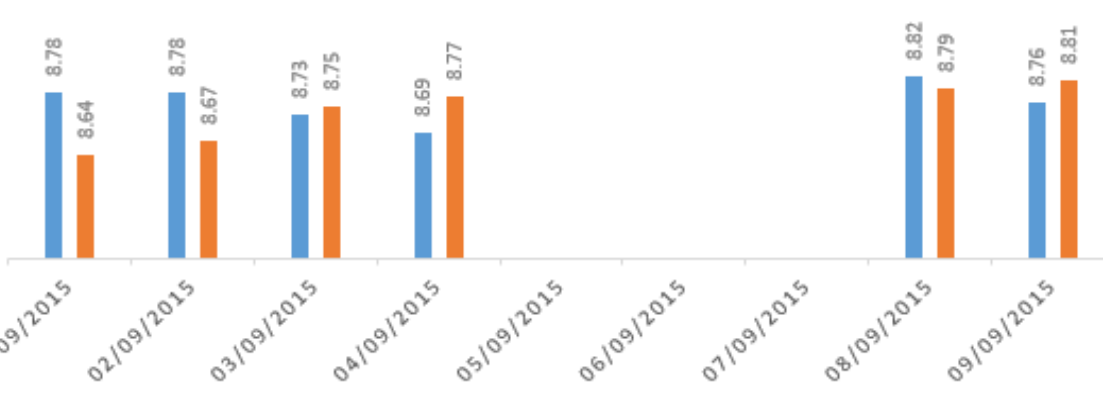

SEPT-2015, MATURING JAN-2016

Figure 5. Contracts negotiated in September 2015, with maturity in January 2016, and spot prices in January 2016.

Source: the authors

Data retrieved from Figure 6 show that forward contract negotiated in September 2016, with maturity in January 2017, had the lowest prices in all maturity dates when compared to spot prices practiced in January 2017. One may say that, in the case of 2016/2017, and compared to the forward contract negotiated in September 2016, producers would have better profits if they traded spot prices in January. 


\section{CONTRACTS 2016/2017 HARVEST}

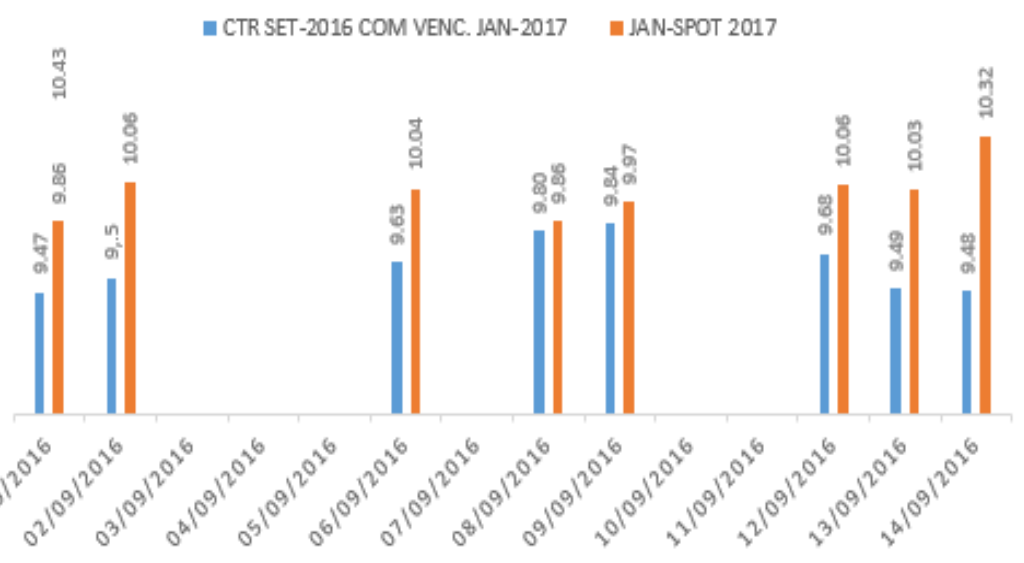

SEPT-2016, MATURING JAN-2017

Figure 6. Contracts negotiated in September 2016, with maturity in January 2017, and spot prices in January 2017. Source: the authors

On the other hand, the Brazilian 2016/2017 harvest reached a record 114 million tons of soybeans, or rather, 18\% more than the amount in the 2015/2016 harvest. Demand was also on the increase, especially by China, which bought 10.2 million tons more than in 2015/2016, reaching 93.5 million tons. In 2017, China alone imported 51.74 million tons of Brazilian soybeans, equivalent to $78.6 \%$ of total Brazilian exports in the previous year. The above restricted a fall in the country's rates (CEPEA, 2018).

Expectations in supply and demand of goods, coupled to substitutes and complements, affect prices. New data on market behavior may change this expectation and price variations occur. Producers have to deal with the great number of market data, trends and reports of institutions that monitor harvest performance.

The Ministry of Agriculture, Livestock and Supply (MAPA), the National Supply Company (CONAB) and the Center for Advanced Studies in Applied Economy (CEPEA) are a reference for the generation of information on production and market in Brazil. In the US, reports by the Department of Agriculture (USDA) are worldwide reference for information on production and harvests, produced for different crops and countries. 
With deep perspicacity, Brazilian producers have increased, year by year, not merely the plantation area but also productivity. However, in terms of results, challenges are huge since an increasing amount of information and data are required for decision taking and to determine the precise moment of commercialization. Foremost, they should benefit from the guarantees and opportunities that the market provides.

\section{FINAL CONSIDERATIONS}

Current research has been limited to harvest years 2011/2012 and 2016/2017, for soybean prices in forward contracts by the CBOY in the US as reference and spot prices practiced by Coopavel in Cascavel, Brazil. It should be underscored that basic analysis and comparison of results on soybean commercialization negotiated on the forward market related to the commercialization of spot market have provided useful data that should be analyzed by agents involved in soybean commercialization.

When seasonality, supply and demand of the commodity soybean are taken into account, forward contracts negotiated in September, with maturity in January, had a better performance when compared to spot contracts in January for the 2011/2012, 2012/2013, 2013/2014 harvests. However, due to fluctuations in climate and market trends, preponderant factors for the 2014/2015, 2015/2016 and 2016/2017 harvests, most contracts with maturity in spot contracts in January had the best prices. However, certain maturity contracts for these harvests revealed that forward contracts in September, with maturity in January, were equal or even higher than spot prices in January. The only exception occurred for the 2016/2017 harvest in which spot contract in January was overall more profitable.

The commercialization of soybean in forward contracts proves to be an interesting alternative for producers that need price guarantees due to the numberless interferences that may occur on the market. In Brazil, agents that are interested in negotiating soybean contracts in forward markets should first contact an authorized stockbroker. In fact, forward markets are always mediated by authorized stockbrokers. Agents should be convinced that negotiating forward contracts is one of the most secure forms with regard to liquidity and fastness. It is highly important that agents interested in participating in the forward market 
know the risks involved in the transactions and they should be aware of the available market tools for attenuating them. In fact, the forward market is one of the most efficient and adequate mechanisms to decrease price risks.

The agents' strategies and aims depend on the formulation of price expectations and on efficient decision taking. So that decisions would be efficient, secure information on market performance are paramount. Forward market is a mode to ensure costs or profits in advance, whilst price control of commodities should be seen as risk management. Consequently, the employment of forward contracts may increase the probability of profits for producers due to the relative predictability between spot and forward prices. Forwards contracts should above all be seen as a form of price guarantee. Commercialization strategy of forward contract may decrease uncertainties caused by market fluctuations.

It may be suggested that agents should make a detailed analysis on the strategy. It should be highlighted that the guarantee of lowest risks and a preestablished and satisfactory result with regard to prices, may establish conditions so that agents would be competitive on the market.

\section{REFERENCES}

AZEVEDO, P. F. de. Comercialização de produtos agroindustriais. In: BATALHA, M. O. (coord.). Gestão agroindustrial: GEPAI: Grupo de Estudos e Pesquisas Agroindustriais. 2. ed. São Paulo: Atlas, 2001.

BM\&FBOVESPA. Bolsa de valores, mercadorias \& futuros. Mercados derivativos. 2012. Available at: https://scalpertrader.com.br/files/2014/09/extrato-futuros-pqo. pdf. Acesso em: 02 jun. 2018.

BM\&F - Bolsa de mercadoria e futuros. Curso de futuros e opções (do Futures Industry Institute). São Paulo, 1998.

CEPEA - Centro de Estudos Avançados em Economia Aplicada. Soja/retro2017: oferta se sobrepõe à demanda e preços são os menores em seis anos. Disponível em: https://www.cepea.esalq.usp.br/br/releases/soja-retro2017-oferta-se-sobrepoe-a-demanda-e-precos-sao-os-menores-em-seis-anos.aspx. Acesso em: 15 dez. 2018. 
CONAB - Companhia Nacional de Abastecimento. Acompanhamento da safra brasileira de grãos. V.5, N.12 - Brasília: CONAB, 2018. Disponível em: https://www.conab. gov.br/component/k2/item/download/22227_378630c35e68682d6a984ecbd43bfe1d. Acesso em: 07 dez. 2018.

CBOT - CHICAGO BOARD OF TRADE. Contract specifications soybeans futures. 1999. Disponível em: http://www.cbot.com/ourproducts/spec37.html. Acesso em: 10 ago. 2017.

CME GROUP. Guia auto-didático para Hedge com Futuros e Opções de grãos e sementes oleaginosas. 2016. Disponível em: https:/www.cmegroup.com/trading/ agricultural/files/AC-216.1_GrainsHedgingGuide_port_SR.pdf. Acesso em: 17 set. 2017.

GIL, A. C. Como elaborar projetos de pesquisa. 4. ed. São Paulo: Atlas, 2002.

HULL, J. Introdução aos mercados futuros e de opções. Tradução de BM\&F (Bolsa de Mercadorias e Futuros). 2. ed. rev. e ampl. São Paulo: BM\&F, 1998.

JESUS-LOPES, J. C. de. Mercado de Capitais. 2007. Disponível em: http://www.unisalesiano.edu.br/ notas/apostilas/Pos_Graduacao/MBA\%20em\%20Finan\%E7as/ Mercado\%20de\%20Capitais/Mercado\%20de\%20Capitais,\%20A\%20Termo,\%20Futuros\%20e\%200p\%E7\%F5es,\%202007.pdf. Acesso em: 05 dez. 2018.

LAZZARINI, S.G. Gerenciamento de riscos de preços no sistema agroindustrial brasileiro da soja. Revista de Economia e Sociologia Rural, Brasília, v. 35, n. 4, p. 41-64, 1997.

LORENZETTI, F. B.; LEISMANN, E. L. Gerenciamento de risco de preço da soja: comparação entre mercados futuros e opções na BM\&Fbovespa como alternativa de hedge. Revista eletrônica científica do CRA-PR, v. 5, p. 111-128, 2018.

MAIA, F. N. de C. da S.; AGUIAR, D. R. D. Estratégias de Hedge com os Contratos Futuros de Soja na Chicago Board of Trade. Gestão \& Produção (UFSCAR. Impresso), v. 17, p. 617-626, 2010.

MAPA - Ministérios da Agricultura, Pecuária e Abastecimento. Complexo Soja. Secretaria de Política Agrícola, Departamento de Crédito e Estudos Econômicos. 2018. Disponível em: http://www.agricultura.gov.br/assuntos/politica-agricola/todas-publi- 
cacoes-de-politica-agricola/sumarios-executivos-de-produtos-agricolas/soja.pdf/view. Acesso em: 07 dez. 2018.

MOTTER, C. C. Comercialização de soja: um instrumento operacional para o aumento da renda do produtor. Florianópolis, 2001, 117 f. Master's (Dissertation in Production Engineering) - Programa de Pós-graduação em Engenharia de Produção, UFSC, 2001.

MARQUES, R. H. S.; AGUIAR, D. R. D. Determinantes do uso de mercados futuros pelos produtores de soja do município de Cascavel, PR. Revista de Economia e Agronegócio, Viçosa, v. 2, n.2, p. 209-233, 2004.

MARQUES, P.V.; MELLO P.C. Mercados futuros de Commodities Agropecuárias. São Paulo: Bolsa de mercadorias \& de Futuros, 1999.

MENDES, J. T. G.; PADILHA, João Batista. Estratégias de comercialização da soja: análise de portfólios, sob condições de risco. Produção (São Paulo), v. 18, p. 441$451,2008$.

MEGLIORINI, Evandir. Custos, São Paulo: ABDR, 2002.

OLIVEIRA JUNIOR, E. F.; CASAROTTO, E. L.; MENDONCA, J. C. A.; BINOTTO, E. . Exportação de Soja no Estado de Mato Grosso do Sul: Características da Comercialização. RAMA : Revista em Agronegócio e meio Ambiente, v. 11, p. 71-97, 2018.

SILVA NETO, L. de A. Derivativos: definições, empregos e riscos. 4. ed. São Paulo: Atlas, 2002.

REZENDE, C. L.; ZYLBERSZTAJN, D. Quebras contratuais e dispersão de sentenças. Revista Direito GV, v. 7, p. 155-176, 2011.

TELSER, L.G., HIGINBOTHAM, H.N. Organized futures markets: costs and benefits. Journal of Political Economy, v. 85, n. 5, p. 969-1000, 1997.

USDA - U.S. DEPARTMENT OF AGRICULTURE. World Agricultural Production. Disponível em: https://www.usda.gov/. Acesso em: 10 jun. 2018.

ZAVAGLIA, A. R.; MASTELLA, M.; KLOECKNER, G. O. Rentabilidade dos contratos 
futuros e de opções das commodities agrícolas soja e milho frente o mercado à vista. In: CONGRESSO VIRTUAL BRASILEIRO DE ADMINISTRAÇÃO, 2011, São Paulo. Anais [...]. São Paulo: Convibra, 2011.

WORKING, H.G. Futures trading and hedge. American Economic Review, v. 63, p. 314-343, 1953.

Recebido em: 08/11/2017

Aceito em: 07/02/2019 